\title{
Interaction of Potassium and Zinc on rice productivity in Iron Toxic soils of Odisha, India
}

\author{
Asit Kumar Pal ${ }^{1}$, Lata Mallik ${ }^{2}$, Bitish Kumar Nayak ${ }^{1 *}$ and Rasmikanta Sahoo ${ }^{3}$
}

${ }^{1}$ Department of Soil Science and Agricultural Chemistry, Institute of Agricultural Sciences, Siksha "O" Anushandhan (Deemed to be University), Bhubaneswar-751029, Odisha, India

${ }^{2}$ Department of Soil Science and Agricultural Chemistry, OUAT, Bhubaneswar-751003, Odisha, India

${ }^{3}$ Department of Agriculture Chemistry and Soil Science Institute of Agriculture Science, University Of Calcutta -700007, Kolkata, India

*Corresponding author

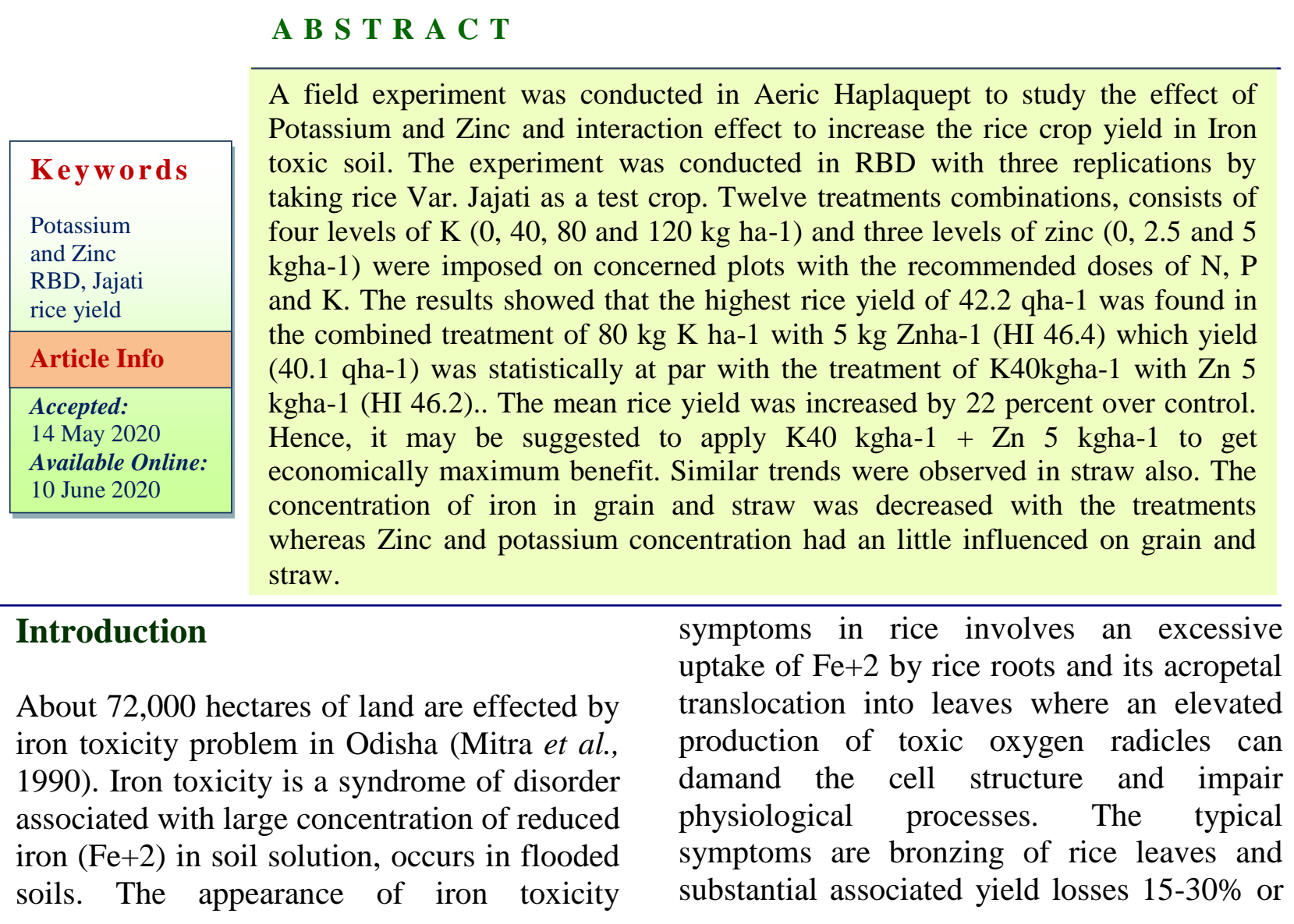


complete crop failure. It is important constraint to rice production mostly micronutrient disorder in wetland rice. Agronomic management was advocated to reduce $\mathrm{Fe}+2$ concentration in soil or cultivars which are tolerant to excess $\mathrm{Fe}+2$. The soil with acidic $\mathrm{pH}$ and high active iron content when get reduced toxic levels of $\mathrm{Fe}$ is produced (Tanaka and Yoshida,1970) A field experiments was laid to screen the scented rice varieties and found that Varities like Acharmati, Khosakani, Thakursuna and CRM-2007-1 were most suitable for iron toxic soils (Pal et al., 2011). Mohanty and Patnaik (1977) observed that K- deficiency aggravated $\mathrm{Fe}$ toxicity. High salt content helps in production of soluble iron through increasing solubility of iron. Sahu and Mitra (1992) observed that increasing dose of K increased the dry matter yield of rice. Application of $\mathrm{K}$ increases $\mathrm{Fe}$ excluding power of root. It depends on root permeability which increase the $\mathrm{K}$ deficiency. The adequate amount of $\mathrm{K}$ produce higher weight molecules which prevent root exudation and entry of soluble iron inside by decreasing root permeability (Benckizer, 1982). Pal et al., (2020) found that application of $40 \mathrm{~kg}$ Kha-1 with 5 kgZnha-1 gave higher rice yield response than Press mud and Ca-silicate. Due to different amendments $\mathrm{Fe}$ concentration in soil was also reduced. Keeping these view, a field study was made by taking $\mathrm{K}$ and $\mathrm{Zn}$ in different doses and their interaction to increase the rice production in Iron toxic soils of Odisha.

\section{Materials and Methods}

A field experiment was conducted during Kharif 2011 in iron toxic low land soil of Central research Station, OUAT, Bhubaneswar. The experiment was conducted in RBD with three replications on a typical iron toxic Aeric Haplaquept soil with recommended dose of fertilizers (N: P: K) by taking rice cultivar 'Jajati' as a test crop. Twelve treatment combinations, consist of four levels of $\mathrm{K}(0,40,80$ and $120 \mathrm{~kg}$ ha- 1$)$ and three levels of zinc (0, 2.5 and 5 kgha-1) were imposed on concerned plots. The soil of the experimental plot was sandy loam with pH 5.1, organic carbon 4.1 gkg-1, CEC 5.0 $\mathrm{Cmol}(\mathrm{P}+) \mathrm{kg}-1$. The available $\mathrm{N}, \mathrm{P}_{2} \mathrm{O}_{5}$ and $\mathrm{K}_{2} \mathrm{O}$ were 185,8 and 95 kgha-1, respectively. The soil had DTPA extractable Fe 400 mgkg1 and $\mathrm{Zn} 1.82$ mgkg-1. The crop was harvested at maturity. Grain and straw yield were recorded. Potassium was estimated by flame photometry method (Jackson,1973). Harvested samples were drying in an oven at $70^{\circ} \mathrm{C}$, then grind. The ground samples were digested with diacid 2:1 mixture of nitric and perchloric acid for chemical analysis. $\mathrm{Zn}$ and Fe content were analysed by Atomic absorption Spectrophotometer (Lindsay and Norvell, 1978).

\section{Results and Discussion}

The rice grain yield varied from 27.5 to 42.2 qha-1 using different treatments (Table 1). Highest significant yield of 42.2 qha-1 ie. 53.6 percent increase over control was obtained with the application of K80 kgha$1+\mathrm{Zn} 5$ kgha-1 (HI 46.4) which was statistically at par with the treatment of K40kgha-1 +Zn 5 kgha-1 (HI 46.2). The application of $\mathrm{K} 40 \mathrm{kgha}-1+\mathrm{Zn} 5 \mathrm{kgha}-$ 1alongwith recommended dose of fertilizers $(\mathrm{N}, \mathrm{P}$ and $\mathrm{K})$ gave rice grain yield of 40.1 qha-1 which was 45.8 percent over control. The effect of $\mathrm{K}$ had significantly increased mean yield over control whereas increasing dose of zinc also had significant effect on yield of rice. The interaction effect of K80 kgha-1 + Zn 5 kgha-1 had no statistical difference with K40 kgha-1 + Zn 5 kgha-1. Hence, it may suggested that application of K@40 kgha-1 + Zn @5 kgha-1 gave better yield of rice and economically maximum benefit. 
Table.1 Effect of Potassium and zinc on yield (qha-1) of rice

\begin{tabular}{|c|c|c|c|c|}
\hline \multirow{2}{*}{ Treatments } & \multicolumn{3}{|c|}{ Yield of rice(qha-1) } & \multirow{2}{*}{ HI(\%) } \\
\cline { 2 - 4 } & Grain & $\begin{array}{c}\text { \% increase over } \\
\text { control }\end{array}$ & Straw & \\
\hline T1-K0Zn0 & 27.5 & - & 34.0 & 44.7 \\
\hline T2-K0Zn2.5 & 32.3 & 17.4 & 38.8 & 45.4 \\
\hline T3-K0Zn5.0 & 34.3 & 24.7 & 40.8 & 45.7 \\
\hline T4-K40Zn0 & 33.4 & 21.3 & 39.9 & 45.6 \\
\hline T5-K40Zn2.5 & 37.0 & 34.5 & 43.5 & 45.9 \\
\hline T6-K40Zn5.0 & 40.1 & 45.8 & 46.6 & 46.2 \\
\hline T7-K80Zn0 & 34.1 & 24.1 & 40.6 & 45.6 \\
\hline T8-K80Zn2.5 & 38.5 & 40.1 & 45.0 & 45.1 \\
\hline T9-K80Zn5.0 & 42.2 & 53.6 & 48.7 & 46.4 \\
\hline T10-K120Zn0 & 34.4 & 25.1 & 39.4 & 46.6 \\
\hline T11-K120Zn2.5 & 36.1 & 31.2 & 42.4 & 45.9 \\
\hline T12-K120Zn5.0 & 37.0 & 34.5 & 42.9 & 46.3 \\
\hline CD (0.05) & 5.89 & - & 5.77 & - \\
\hline
\end{tabular}

Table.2 Effect of Potassium and zinc on Fe, Zn (mgkg-1) and $\mathrm{K}(\%)$ content in rice

\begin{tabular}{|c|c|c|c|c|c|c|}
\hline \multirow{2}{*}{ Treatments } & \multicolumn{2}{|c|}{ Fe conc.(mgkg-1) } & \multicolumn{2}{|c|}{ Zn conc.(mgkg-1) } & \multicolumn{2}{c|}{ K(\%) } \\
\cline { 2 - 7 } & Grain & straw & Grain & Straw & Grain & straw \\
\hline T1-K0Zn0 & 82.2 & 237.5 & 24.8 & 34.5 & 0.16 & 0.32 \\
\hline T2-K0Zn2.5 & 66.5 & 120.6 & 25.3 & 33.9 & 0.16 & .041 \\
\hline T3-K0Zn5.0 & 61.6 & 101.9 & 26.3 & 30.9 & 0.15 & 0.37 \\
\hline T4-K40Zn0 & 77.9 & 164.7 & 25.7 & 41.4 & 0.19 & 0.40 \\
\hline T5-K40Zn2.5 & 67.9 & 146.9 & 26.5 & 41.7 & 0.17 & 0.34 \\
\hline T6-K40Zn5.0 & 43.3 & 127.1 & 24.8 & 43.9 & 0.17 & 0.42 \\
\hline T7-K80Zn0 & 74.6 & 148.4 & 29.0 & 42.4 & 0.15 & 0.36 \\
\hline T8-K80Zn2.5 & 57.3 & 119.9 & 26.9 & 40.8 & 0.18 & 0.25 \\
\hline T9-K80Zn5.0 & 69.9 & 111.2 & 23.9 & 39.8 & 0.17 & 0.33 \\
\hline T10-K120Zn0 & 70.4 & 198.3 & 26.5 & 35.9 & 0.17 & 0.36 \\
\hline T11-120Zn2.5 & 60.9 & 98.8 & 26.1 & 34.6 & 0.17 & 0.32 \\
\hline T12-120Zn5.0 & 59.2 & 72.2 & 25.4 & 34.1 & 0.15 & 0.36 \\
\hline CD (0.05) & 29.6 & 45.15 & 5.41 & 8.32 & 0.04 & 0.14 \\
\hline
\end{tabular}

Similar trends were observed in case of straw. The findings made by Nayak and sahu (2008), found that $\mathrm{K} @ 80$ kgha-1 was the best treatment followed by lime, fresh cowdung, fly ash and others in sequence. Pal et al., (2020) was obtained similar results with the application of $\mathrm{K} 40 \mathrm{~kg}$ ha-1 through Patent kali $+\mathrm{Zn} 5 \mathrm{kgha}-1$ to rice yield may be due to $\mathrm{K}$ and $\mathrm{Zn}$ which increases the root exudation and convert soluble $\mathrm{Fe}+2$ to insoluble $\mathrm{Fe}+3$ in rhizosphere (Tanaka and Yoshida,1970). Adequate quantity of $\mathrm{K}$ prevents root exudation and entry of soluble iron inside by decreasing root permeability (Benckizer 1982).

The content of $\mathrm{Fe}, \mathrm{Zn}$ (mgkg-1) and $\mathrm{K}(\%)$ in grain and straw are presented in Table 2. It was found that $\mathrm{Fe}$ content in grain and straw varied from 43.3 to $82.2 \mathrm{mgkg}-1$ and 72.2 to 
237.5 mgkg-1, respectively. Highest $\mathrm{Fe}$ content of 82.2 mgkg-1 in grain and 237.5 mgkg-1 in straw was observed in control. Gradually it was decreased with the treatments. Lowest Fe content of grain (43.3 mgkg-1) was observed in the treatment of K@40Kgha-1 + Zn@ 5kgha-1 may be due to $\mathrm{K}$ and $\mathrm{Zn}$ decreased the solubility of $\mathrm{Fe}$ concentration in soil, as a result less Fe uptake by rice. Zinc content in grain ranged from 23.9 to 29.0 mgkg-1 whereas in straw it varied from 30.9 to 43.9 mgkg-1.The potassium percentage in grain and straw varied from 0.15 to 0.19 and from 0.25 to 0.42 percent, respectively. It was found that with increasing level of $\mathrm{K}, \mathrm{Fe}$ content in grain was decreased, further decreased was noticed with the addition of zinc.

From the study, it may be concluded that the application of K @40 kgha-1 and Zn@5 kgha-1was the best treatment to enhance better grain yield of rice and gave economically maximum benefit in iron toxic soil.

\section{References}

Benckizer G; Ottow JCG; Santiago S and Watanabe I.(1982) Physiochemical characteristics of Iron toxic soils in some Asian ountries. IRRI Res. Paper series-85, IRRI, Manila, Philippines.

Jackson ML(1973) ;Soil Chemical Analysis. Prentice Hall of India (Pvt) Ltd. New

\section{Delhi}

Lindsay WI and Norvel WA (1978). 'Development of DTPA soil test for Zinc, iron, Manganese and copper'. Soil Science Am.J. 42: 421- 448.

Mitra GN; Sahu S and Dev G (1990). 'Potassium chloride increases rice yield and reduce the symptom of iron toxicity'. Better crops Inter, 12: 14-15.

Mohanty SK and Patnaik S (1997). Effect of submergence on the chemical changes in different rice soils. The kinetics of $\mathrm{K}$, $\mathrm{Ca}$ and $\mathrm{Mg}$. Acta Agronimica, Acad,Sci. hungery, 26: 187- 192.

Nayak RK and Sahu SK (2008). 'Studies on Iron toxicity in relation to rice nutrition in soils of Orissa'. Ph.D thesis submission to santiniketan, W.B.

Pal AK ; Nayak BK and sahoo RK (2020).' Impact of different amendments on rice productivity in iron toxic soils of Odisha'. International J. chemical studies 8(3) : 490- 492.

Pal AK ; Nayak RK and Acharya R (2011).' Screening of scented rice genotypes under Iron toxic soil'.J.Res. Orissa Univ. Agric. Tech. special issue 1(1): 164-167.

Sahu SK and Mitra GN (1992).' Iron Potassium interaction of nutrient balance in rice'. J.Potassium Res. 8(4): 311-319.

Tanaka A and Yoshida S (1970). 'Nutrient disorder of rice plant in Asia' Bull. No. 10, IRRI, Manila, Philippines.

\section{How to cite this article:}

Asit Kumar Pal, Lata Mallik, Bitish Kumar Nayak and Rasmikanta Sahoo. 2020. Interaction of Potassium and Zinc on rice productivity in Iron Toxic soils of Odisha, India. Int.J.Curr.Microbiol.App.Sci. 9(06): 303-306. doi: https://doi.org/10.20546/ijcmas.2020.906.039 